УДК 1:17(09)

DOI: 10.18101/1994-0866-2020-2-54-60

\title{
ФИЛОСОФЫ ДРЕВНОСТИ О МИРОЛЮБИИ И СОГЛАСИИ
}

\section{(C) Чимитова Ирина Зоригтоевна}

кандидат социологических наук, старший преподаватель, Бурятская государственная сельскохозяйственная академия имени В. Р. Филиппова Россия, 670024, г. Улан-Удэ, ул. Пушкина, 8

E-mail: rindaol@mail.ru

Социальная философия и этика изучали толерантность и согласие в течение многих столетий. На ранних этапах философствования высказывались лишь идеи или проблески идей относительно этих явлений. Базовые представления о них, сформулированные в «золотом правиле» нравственности, в трудах мыслителей древности рассматривались в связи с их суждениями об основополагающих принципах и ценностях их учений: человеколюбии, благородстве, справедливости, дружелюбии и др. Ввиду отсутствия в тот период термина «толерантность» для обозначения соответствующего явления автор данной статьи использует слово «миролюбие», т. к. его проявления привлекали внимание большинства мыслителей древности. Конфуций акцентировал внимание на проявлениях миролюбия, обсуждая в то же время и отношения согласия. Марк Аврелий, напротив, отдавал предпочтение согласию. Платон тоже много размышлял о согласии в обществе. Аристотель рассуждал о дружеских отношениях, которые также входят в смысловое поле согласия. Большинство этих идей актуальны и сегодня.

Ключевые слова: толерантность; миролюбие; согласие; «золотое правило» нравственности; конфуцианство; древнегреческая философия; человеколюбие; благородство; справедливость; дружелюбие.

\section{Для цитирования}

Чимитова И. 3. Философы древности о миролюбии и согласии // Вестник Бурятского государственного университета. Философия. 2020. Вып. 2. С. 54-60.

В число идей, которые хотя и разрабатывались в истории социальной философии и этики в течение многих столетий, сегодня не только не потеряли своей актуальности, но и более того - являются насущными для современного сложного и противоречивого мира, то и дело балансирующего на грани локальных и региональных катастроф, входят тесно взаимосвязанные, но не тождественные идеи толерантности и согласия.

В древности разные авторы обозначали сами эти явления по-разному.

В силу неразвитости науки они смогли высказать, главным образом, лишь отдельные идеи или проблески идей относительно их сущности и проявлений. Поэтому применительно к ранним этапам истории философии приходится рассматривать не только толкование обозначений, не ставших еще понятими собственно согласия, а тем более толерантности, т. к. обозначающий ее термин появился намного позже, но и смысл ряда синонимов.

«Золотое правило» нравственности, изложенное еще в «Махабхарате», Библии и других сочинениях древности, содержало базовое представление о толерант- 
ности. Гуманизм этого требования за несколько тысячелетий нисколько не потерял в своей значимости и по-прежнему состоит в утверждении необходимости одного участника социального взаимодействия поставить себя на место другого, чтобы относиться к нему справедливо и как к равному себе. Именно справедливость и равенство мы считаем ядром «золотого правила».

Прежде чем обратиться к воззрениям Конфуция, необходимо отметить, что его размышления во многом перекликаются с суждениями философов Древней Греции. Не случайно многие востоковеды считают сопоставимыми философию Древнего Китая и античности, усматривая в них элементы рационализма, диалектики, системности и т. д.

Подобно многим мудрецам древности, Конфуций высказал лишь ряд суждений, сопряженных с толерантностью, которые условно можно обобщить под названием «миролюбие», а также с согласием. Придавая особую значимость ключевым ценностям, он включил в их смысловое поле и миролюбие, и согласие.

Занимающее первостепенное место в его философии многозначное понятие «жэнь» - человеколюбие, переводимое также и как человечность, гуманность и др. [1, с. 190-193], Конфуций определял, например, как «осторожность в речах» [2, с. 108], что является одним из проявлений миролюбия. С тех пор интенсивность социальных коммуникации неизмеримо возросла, но осторожность в выражениях все так же является условием успешности общения социальных субъектов.

Среди ключевых ценностей мыслитель высоко ценит гармонию, неотрывную от прекрасного, считая ее свойственной отношениям согласия между людьми. В современной эстетике гармония по-прежнему считается атрибутом прекрасного.

Считаем, что гармония между людьми как высшее проявление миролюбия в реальности встречается нечасто, но даже минимальное миролюбие предпочтительнее его антипода.

Гармония - одно из качеств конфуцианского «благородного мужа», наряду с уступчивостью, сдержанностью и искренностью. Но значительно важнее, по нашему убеждению, то, что благородные признают за основу справедливость, живут в согласии и стремятся к нему [2, с. 148].

Мыслитель размышлял о понятии «жэнь» в непосредственной связи с часто используемым им понятием любви к людям (господство любви, царство любви), называя такие отношения прекрасными [2, с. 116, 43]. Под любовью он подразумевал дружбу, общность интересов, взаимопонимание, эмпатию, духовную близость, даже родственность людей, т. е. соотносил ее даже с более теплыми и глубокими отношениями, нежели отношения согласия.

Можно согласиться с Конфуцием в том, что уступчивость, как и осторожность, — проявление миролюбия, а справедливость и особенно искренность - атрибуты согласия.

Он сформулировал актуальные везде и всегда общечеловеческие требования, соответствующие «золотому правилу»: платить добром за добро и справедливостью за зло, заботиться о младших, любить и уважать старших по возрасту, быть искренним, скромным, внимательным к людям.

Не столь универсальны некоторые заповеди, имеющие «китайскую», шире «восточную специфику» и временную обусловленность. К ним относится призыв 
любить и уважать старших по общественному положению, выражающий свойственные и ныне многим странам Востока чинопочитание и пиетет по отношению к лицу, имеющему более высокий формальный статус. В этом вопросе Конфуций отступает от справедливости и особенно от равенства и проявляет себя человеком своего времени, как и в отношении людей, не являющихся «благородными мужами», «избранными». Известны его нелестные оценки «не избранных», обычных людей, например женщин, слуг и т. д.

Хотя низкий статус многих таких групп населения закреплен в морали и праве некоторых стран, в развитых государствах это выглядит анахронизмом. Здесь основатель конфуцианства тоже отходит от фундаментальных принципов «золотого правила», и критиковать его с позиций нашего времени было бы несправедливо, но и не замечать отступлений от «золотого правила» было бы необъективно.

Впрочем, в некоторых суждениях китайский философ демонстрирует широту взглядов, призывая к миролюбивому и даже искреннему общению с людьми независимо от их статуса (даже с дикарями), говоря, что со всеми следует обращаться как со знатными гостями [2, с. 108, 123].

Некоторые исследователи оценивают толерантность в конфуцианском понимании как «добродетель, близкую по смыслу к примиренчеству» [см., например: 3, c. 20].

Полагаем, что миролюбие не тождественно примиренчеству, оно, более глубоко выражая внутреннюю мотивацию субъекта, подразумевает взаимодействие обеих взаимодействующих сторон. Кроме того, по нашему мнению, в «золотом правиле» доминирует действенное начало, а не пассивная позиция и отмеченная выше способность субъекта поставить себя на место другого.

Свидетельством того, что во многом учение Конфуция адекватно духу и букве «золотого правила», являются прямые указания, выраженные в императивной форме, например: «чего не желаешь себе, не делай и другим...» [2, с. 108, 108].

Итак, идеи Конфуция, за некоторыми исключениями, обусловленными конкретными обстоятельствами, созвучны «золотому правилу». В его сочинениях осмысливаются такие явления, как миролюбие и согласие.

Дальнейшее развитие представлений о миролюбии и согласии происходило преимущественно в европейской социально-философской и этической мысли.

Философы античности уделяли большое внимание этическим аспектам миролюбия и согласия, анализируя, главным образом, личностные качества, отношения между людьми и т. д.

Так, Пифагор обратил внимание на такое свойство характера человека, как «умение слушать других», а Платон — на уживчивый нрав. Оба эти качества проявления миролюбия.

Справедливость имела основополагающее значение и для Платона. В «Комментариях» к его «Государству» это произведение правильно характеризуется как «развернутое определение справедливости как важнейшей философской категории» $[4$, с. 802$]$. Именно в процессе обоснования и всестороннего анализа этого этического понятия мыслитель говорил о миролюбии, от имени Сократа утверждая, что «не дело справедливого человека вредить - ни другу, ни кому-либо иному» [5, с. 17]. 
А. Е. Кузнецов убедительно показывает главенство в воззрениях Платона справедливости над остальными добродетелями и ее тесную связь с гармонией и согласием, подчеркивая, что «укоренившись в душе, справедливость надзирает, чтобы разум повелевал, воля реализовывала эти повеления, а страсти удерживались в границах. Такая гармония и согласие есть благость для человека...» 6 , c. 37].

Установлению и поддержанию мира в социуме могло бы способствовать требование участников дебатов о государстве предоставить всем сословиям возможность получать свою долю в общем процветании, а также положение о необходимости со стороны помощников правителей кротко и доброжелательно относиться к гражданам $[5$, c. 146,141$]$. Эта проблема актуальна и в наше время и, к сожалению, довольно остро стоит в России с ее высоким уровнем бедности, наличием огромного числа работающих бедных, многие из которых добросовестно трудятся и имеют высокую квалификацию, резкой поляризацией общества по доступу к ресурсам и по целому ряду других параметров, с отчужденностью бюрократии от населения, а иногда - с грубостью и неприкрытым хамством отдельных должностных лиц.

В своей модели идеального государства Платон ограничивал свободу выбора для стражей и чрезмерно регламентировал их жизнь и воспитание, стремясь педантично запрограммировать способы обойти все «подводные камни», «оберегая» их от любых потенциально нежелательных воздействий, даже от изображенных в искусстве драматических, трагических и т. п. сцен и сюжетов.

Здесь основатель Академии не следовал «золотому правилу» - принципам справедливости и равенства, ибо лишение свободы другого субъекта является таковым, а также показал неспособность поставить себя на место будущих стражей. Тем не менее философ употребил важное для рассматриваемой темы словосочетание «дружба и согласие», которые якобы должны внушать воспитуемым разрешенные вышестоящими лицами произведения» [5, с. 117], по-видимому, считая их явлениями одного порядка.

Понятие взаимопомощи, тоже близкое к термину «согласие», он использовал для объяснения одной из причин появления государства: «Испытывая нужду во многом, многие люди собираются воедино, чтобы обитать сообща и оказывать друг другу помощь...» [5, с. 68].

Следовательно, больший интерес Платон проявил к миролюбию, в понимании которого исходил из принципа справедливости, интерпретируя его как и отсутствие вражды, и отказ от того, чтобы вредить не только ближнему, но и любому человеку, и уживчивость, и мир в обществе.

Активно развивал идеи миролюбия и Аристотель. Он полагал, что государству не нужны завоевания, а воспитывать граждан надо в духе гуманности. Человек как общественное существо нуждается в других людях, и достичь высшего блага без общения с ними невозможно.

Фактически о миролюбии, в духе «золотого правила», он рассуждал, говоря о людях, обладающих добродетелью, позволяющей им в общении с незнакомыми опираться на предположение о доброте и полезности последних и одинаково вести себя с незнакомыми и знакомыми, близкими и посторонними. 
Проявляя справедливость, Аристотель допускал участие граждан в управлении без дискриминации их по возрасту, в отличие от Платона, считавшего предпочтительным для этой деятельности время акме.

Более того, мыслитель, в противовес высокомерию некоторых своих современников, да и нынешних сторонников этноцентризма, распространил принцип миролюбия за границы полиса, всей Эллады, полагая, что ядро характера граждан идеального государства, в основе своей греческое, может быть обогащено лучшими чертами других народов.

Актуален аристотелевский анализ понятия справедливости и его антипода. На основе понятий меры и пропорции он оценивал как зло и страдание от несправедливости, и в особенности несправедливые поступки. Справедливыми он именовал требования разума, берущего верх над страстями и делающего людей миролюбивыми.

Философ уделил много внимания такой черте характера, как дружественность, и дружбе между людьми, считая, что последняя «не только нечто необходимое, но и нравственно прекрасное». Более того, он распространил эти добродетели и на межгосударственные связи: «Дружественность, по-видимому, скрепляет и государства» [7, с. 219-220].

Аристотель показал разницу между дружбой, характеризующей, по нашему мнению, отношения согласия, и расположением к людям (которое, полагаем, имеет место и на уровне миролюбивых отношений), несмотря на их схожесть. В расположении, считал он, «нет ни напряжения, ни стремления, а они сопутствуют чувству дружеской привязанности. Кроме того, чувство привязанности обусловлено [длительной] взаимной близостью... а расположение может возникнуть внезапно... и приязнь тут испытывают поверхностно» [7, с. 252]».

Он проявил проницательность, заметив фактор длительности в случае дружеской привязанности. Отличительным качеством такого близкого к дружбе явления, как согласие, тоже является, по мнению современных исследователей, длительность контактов [8, с. 28].

Стагирит подчеркивал искренность и открытость дружбы, отмечая, что друзья желают друг другу «благ вообще, причем так, чтобы это не оставалось в тайне...» $[7$, с. 221$] »$.

Обобщая идеи Аристотеля, можно заметить, что в его трудах тоже большое место уделено справедливости. Продолжил он традиции своих предшественников и в анализе разнообразных ипостасей миролюбия. Обстоятельно размышлял философ и о таком родственном согласию явлении, как дружба.

Стагирит подчеркивал искренность и открытость дружбы, отмечая, что друзья желают друг другу «благ вообще, причем так, чтобы это не оставалось в тайне...» $[7$, с. 221$] »$.

Таким образом, Аристотель тоже уделил внимание изучению справедливости, миролюбию и дружбе.

Особенностью стоицизма являются мотивы всеобщего братства людей. В этом ключе стоики подчеркивали духовную органическую связь человека с человечеством и мировым целым и отмечали его «обязанность жить для целого, человеколюбиво относиться к себе подобным» $[9$, с. 476]. Не случайно один из них, 
Марк Аврелий, призывал: «от всего сердца люби людей, с которыми тебе суждено жить» [10, с. 79].

Он указывал на разные проявления миролюбия. С одной стороны, верный постулатам своих единомышленников-стоиков он демонстрирует примеры пассивности и смирения, вопрошая: «Кто-нибудь поступает плохо по отношению ко мне?», и отвечая: «Что ж, это его дело. У него свое душевное настроение и свой образ действий» [10, с. 68] и советуя: терпи; чтобы оборониться от обиды, надо уподобиться обидчику; если не можешь исправить заблуждающегося, отнесись к нему благожелательно [10, с. 72, 107, 114].

С другой стороны, он предпринял попытку внушить своим читателям необходимость более заинтересованного и внимательного отношения к окружающим, вплоть до того, чтобы вникать «в душу говорящего» [10, с. 114].

Таким образом, в сочинениях выдающихся мыслителей древности - Конфуция, Платона, Аристотеля, Марка Аврелия - рассмотрены существенные аспекты миролюбия и согласия, многие из которых не потеряли актуальности, прослеживается их связь с «золотым правилом» нравственности, высказаны также суждения относительно близких к ним явлений.

\section{Литература}

1. Переломов Л. С. Конфуций: жизнь, учение, судьба. М.: Наука; Восточная литература РАН, 1993. 440 c.

2. Конфуций. Суждения и беседы / пер. с кит. П. Попова. СПб.: Лениздат; Команда A, 2013. $192 \mathrm{c}$.

3. Касьянова Е. И. Социально-философские основания толерантности: автореф. дис. ... д-ра филос. наук. Улан-Удэ, 2009. 46 с.

4. Древнегреческая философия: от Платона до Аристотеля / пер. с лат. и древнегреч. М.: АСТ; Харьков: Фолио, 2003. 829 с.

5. Платон. Государство / пер. с древнегреч. А. Н. Егунова. М.: АСТ, 2018. 448 с.

6. Кузнецов А. Е. Философские максимы обществознания. Улан-Удэ: РИО Бурятской государственной сельскохозяйственной академии, 1999. 260 с.

7. Аристотель. Никомахова этика // Соч.: в 4 т. М.: Мысль, 1984. С. 53-293.

8. Чимитова И. 3. О соотношении понятий «толерантность» и «согласие» // Вестник Бурятского государственного университета. Философия. 2018. № 3. Т. 3. С. $25-31$.

9. Трубецкой С. Н. Курс истории древней философии. М.: Владос, 1997. 576 с.

10. Марк Аврелий. Размышления (Наедине с собой); Дигенис Акрит. М.: ТЕРРА Книжный клуб, 2009. 411 с.

\section{ANCIENT PHILOSOPHERS ABOUT PEACEFULNESS AND HARMONY}

\section{Irina Z. Chimitova}

Cand. Sci. (Sociol.), Senior Lecturer,

Filippov Buryat State Agricultural Academy

8 Pushkina St., Ulan-Ude 670024, Russia

E-mail: rindaol@mail.ru.

Social philosophy and ethics have studied tolerance and harmony for centuries. In the early stages of philosophizing, the sophists have only ideas or glimpses of ideas regarding 
these phenomena. The views on these concepts were formulated in the "golden rule" of morality, in the writings of ancient thinkers in connection with their judgments about the fundamental principles and values of their teachings: humanity, nobleness, justice, friendliness, etc. Since there was no a term "tolerance" in ancient times, we use the word "peacefulness" to denote the corresponding phenomenon, because its manifestations attracted the attention of most thinkers of ancientry. Confucius focused on the manifestations of peacefulness, and having discussed also the relations of harmony. Marcus Aurelius, on the contrary, preferred to focus on the phenomenon of harmony. Plato also thought a lot about harmony in society. Aristotle discussed friendship as a part of the semantic field of harmony. Most of these ideas are relevant today.

Keywords: tolerance; peacefulness; harmony; the "golden rule" of morality; Confucianism; ancient Greek philosophy; benevolence; nobileness; justice; friendliness. 